\title{
Relationship of Trunk Size to Selected Canopy Size Parameters for Native Pecan Trees
}

\author{
Michael W. Smith ${ }^{1}$ \\ Department of Horticulture and Landscape Architecture, Oklahoma State \\ University, Stillwater, OK 74078
}

Additional index words. Carya illinoinensis, tree spacing, bearing surface, tree density, canopy volume, trunk cross-sectional area, yield potential, production

\begin{abstract}
Trees in a native pecan [Carya illinoinensis (Wangenh.) C. Koch.] grove vary in size, age, and genotype and tree spacing pattern is not uniform. This presents some problems for managing tree density, calibrating pesticide sprayers, and other management tasks. Trunk and canopy diameters and tree height of diverse sizes of native pecan trees in managed groves were measured and the relationships of cross-sectional trunk area with canopy footprint, surface area, and volume were determined. The canopy footprint, surface area, and volume per hectare were then calculated for the recommended stocking density of $6.9 \mathrm{~m}^{2} \cdot \mathrm{ha}^{-1}$ of cross-sectional trunk area. Cross-sectional trunk area was strongly correlated with canopy footprint, surface area, and volume. Groves with an average tree size between 0.02 and $0.75 \mathrm{~m}^{2} \cdot \mathrm{ha}^{-1}$ cross-sectional trunk had $\approx \mathbf{5 0} \%$ canopy cover per unit land area and $3 \mathrm{ha} \cdot \mathrm{ha}^{-1}$ bearing surface per unit land area at the recommended stocking density.
\end{abstract}

Pecan is an indigenous nut tree that has been growing over its present range in the United States for at least 8000 years (Hall, 2000). The native habitat of pecan is the mixed-stand riparian forests in the central United States extending into Mexico (Sparks, 2005). Archaeological and ethno-historic data indicated that it was an important food source for people inhabiting areas within its range during prehistoric and early historic times (Hall, 2000). Today, pecans remain a valued food source for a health-conscious public.

Pecans are produced in the United States from both native stands and planted orchards (Reid, 2002). Approximately $30 \%$ of pecans marketed in the United States are from native trees (Pollack, 2001), and 90\% of those produced in Oklahoma are from native stands (Smith, 2006). Planted pecan orchards are similar to other tree fruit orchards in that they consist of limited genetic diversity (two or more cultivars) with trees planted in selected patterns at a fixed spacing. A unique characteristic of pecan orchards is they are planted with two planned tree removals to prevent excessive crowding during orchard life (Carroll et al., 2006).

Development of a native pecan grove consists of selecting an area with abundant pecan timber, removal of all woody species except pecan, and then thinning excess pecan trees to

Received for publication 19 Dec. 2007. Accepted for publication $24 \mathrm{Jan} .2008$.

Approved for publication by the Oklahoma Agricultural Experiment Station.

Funding for this study was provided by the Oklahoma Agricultural Experiment Station and the Oklahoma Pecan Growers' Association.

${ }^{1}$ To whom reprint requests should be addressed; e-mail mike.smith@okstate.edu pecan tree stands in central Oklahoma, determined that maximum productivity occurred when tree density was $6.9 \mathrm{~m}^{2} \cdot \mathrm{ha}^{-1}$ crosssectional trunk area $\left(30 \mathrm{ft}^{2} /\right.$ acre cross-sectional trunk area). This result has been used as a guide for managing native tree density throughout Oklahoma (McCraw, 2006). Optimum tree density may be affected by climate, particularly rainfall, and soil characteristics. However, unless a particular input is excessively restrictive such as annual rainfall (Romberg et al., 1959), guidelines developed by Hinrichs (1961) should be suitable when sunlight is the primary input that limits production.

Allometric equations to estimate biomass have been developed for orchard-grown pecan trees (Smith and Wood, 2006). Equations relating trunk size with canopy size characteristics of native pecan trees would be useful to define tree density for maximizing productivity, aid in sprayer calibration for pesticide application, and for research applications. The objective of this study was to develop equations that relate trunk measurements to selected canopy size parameters and then use those equations to elucidate certain canopy characteristics at optimum tree density as defined by Hinrichs (1961).

\section{Materials and Methods}

Pecan trees were measured at three locations in Oklahoma: Madill (southern; long. $34.09153^{\circ} \mathrm{N}$, lat. $97.77232^{\circ} \mathrm{W}$ ), Stillwater (central; long. $36.09133^{\circ} \mathrm{N}$, lat. $97.06682^{\circ} \mathrm{W}$ ), and Sapulpa (eastern; long. $35.96653^{\circ} \mathrm{N}$, lat. $\left.96.10077^{\circ} \mathrm{W}\right)$. Trees in the study had been under continuous management for more than 40 years. Distance between canopies indicated that light interception and area for canopy development were not restricted by adjacent trees. At Madill and Sapulpa, only native trees were measured. Trees at Stillwater included both native trees (primarily) and a few grafted (cultivar) trees of various cultivars on native rootstocks. Trees were selected at each site to avoid those with adjacent trees that might affect canopy development, to represent a range in sizes, and to avoid those with misshapen canopies resulting from storm damage. Canopy shape of cultivar trees included at the Stillwater site was similar to the native trees. Twenty to 30 trees were measured at each site. Trees ranged from 17 to $97 \mathrm{~cm}$ in trunk diameter at $1.4 \mathrm{~m}$ above the ground. Measurements included canopy diameter measured in one direction and then at a right angle to the first measurement, tree height using a clinometer, and trunk diameter at $1.4 \mathrm{~m}$ above the ground with a diameter tape.

The canopy shape of a native pecan tree most closely resembles a cylinder, i.e., the canopy footprint (canopy coverage) is roughly round with relatively straight vertical sides, and a flat top. The following formulas were used to calculate variables.

Cross-sectional trunk area: $\mathrm{T}=0.7854 \mathrm{D}_{\mathrm{t}}{ }^{2}$

Canopy footprint: $\mathrm{F}=0.7854\left(\mathrm{D}_{\mathrm{c} 1} \times \mathrm{D}_{\mathrm{c} 2}\right)$

$$
\begin{aligned}
& \text { Canopy surface area: } \\
& \qquad \begin{array}{c}
\mathrm{S}=\mathrm{F}+\mathrm{H}\left\{3.1416\left[\left(\mathrm{D}_{\mathrm{c} 1}+\mathrm{D}_{\mathrm{c} 2}\right) / 2\right]\right\} \\
\text { Canopy volume: } \mathrm{V}=\mathrm{F} \times \mathrm{H}
\end{array}
\end{aligned}
$$

where $\mathrm{T}$ is the cross-sectional trunk area in meters squared; 0.7854 is a constant; $\mathrm{D}_{\mathrm{t}}$ is the trunk diameter in meters measured $1.4 \mathrm{~m}$ above the ground; $\mathrm{F}$ is the canopy footprint in meters squared; $\mathrm{D}_{\mathrm{c} 1}$ and $\mathrm{D}_{\mathrm{c} 2}$ are the canopy 
diameters in meters at right angles from each other, $\mathrm{S}$ is the surface area in meters squared; 3.1416 is a constant; $\mathrm{H}$ is the height of the tree in meters; and V is the canopy volume in meters cubed. It should be noted that one end of the cylinder was omitted from the surface area calculation because the bottom of the canopy is shaded and unproductive.

The relationships between trunk crosssectional area and selected canopy parameters were determined using least squares techniques (Draper and Smith, 1966). Tree density and selected canopy characteristics per unit area were calculated using equations derived previously and the recommended stocking density for native pecan trees of $6.9 \mathrm{~m}^{2} \cdot \mathrm{ha}^{-1}$ cross-sectional trunk area (Hinrichs, 1961). For example,

$$
\mathrm{S}_{\mathrm{ha}}=(172+3717 \mathrm{~T}) \times 6.9 / \mathrm{T} / 10,000
$$

where $\mathrm{S}_{\mathrm{ha}}$ is the canopy surface area per unit land area in ha ha $^{-1} ; 172$ is the y intercept; and 3717 is the slope to estimate the canopy bearing surface in $\mathrm{m}^{2}$ using trunk crosssectional area $(\mathrm{T})$ in $\mathrm{m}^{2} ; 6.9$ is the recommended tree stocking density in $\mathrm{m}^{2} \cdot \mathrm{ha}^{-1}$ cross-sectional trunk area; and dividing by 10,000 converts $\mathrm{m}^{2}$ into hectare. Other canopy characteristics were calculated in a similar manner.

\section{Results and Discussion}

Trunk cross-sectional area and canopy footprint were strongly correlated (Fig. 1). One metric frequently used to determine proper tree density is $50 \%$ shade at solar noon (McCraw, 2006), equivalent to $50 \%$ canopy footprint. Because trunk cross-sectional area is a good predictor of canopy footprint for an individual tree, the canopy footprint per unit land area associated with the recommended stocking rate of $6.9 \mathrm{~m}^{2} \cdot \mathrm{ha}^{-1}$ cross-sectional trunk area (Hinrichs, 1961) for various size trees can be calculated with reasonable accuracy. Canopy footprint is $\approx 50 \%$ for trees with cross-sectional trunk areas of $0.2 \mathrm{~m}^{2}$ (50 cm diameter) through $0.75 \mathrm{~m}^{2}$ (98 cm diameter) at the recommended stocking density (Fig. 2). This requires 35 trees/ha for trees with trunks $0.2 \mathrm{~m}^{2}$ and 9 trees/ha for trees with $0.75-\mathrm{m}^{2}$ trunks. However, smaller trees have a larger cumulative footprint when stocked at $6.9 \mathrm{~m}^{2} \cdot \mathrm{ha}^{-1}$ cross-sectional trunk area. For example, the

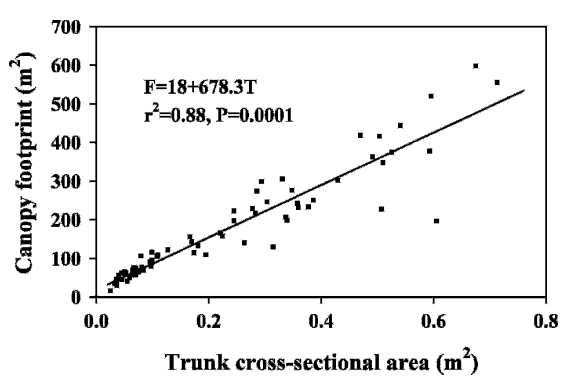

Fig. 1. The relationship between pecan tree crosssectional trunk area $(\mathrm{T})$ measured $1.4 \mathrm{~m}$ above the ground with the canopy footprint $(\mathrm{F})$. smallest trees included in this study had a trunk area of $0.04 \mathrm{~m}^{2}$, requiring 173 trees/ha for optimum stocking density, resulting in a $79 \%$ canopy footprint. It would be rare for a managed grove to exceed 90 trees/ha because these would be relatively small trees by pecan standards and require tree removal within an exceedingly short timespan to prevent crowding. Trees in Hinrichs' (1961) study averaged $0.55 \mathrm{~m}^{2} /$ tree cross-sectional trunk area; thus, tree size was within the range where approximately a $50 \%$ canopy footprint was a reasonable estimate for optimum spacing. In native groves, tree sizes vary widely, but in most instances, the average tree size exceeds $0.2 \mathrm{~m}^{2} \cdot \mathrm{ha}^{-1}$ cross-sectional trunk area.

Tree height and canopy diameter were closely related to trunk cross-sectional trunk area (Fig. 3). The slopes were similar for tree height and canopy diameter, indicating that growth in height and width occurs at approximately the same rate when trees are not excessively crowded as would be the case in a managed native orchard. This differs substantially from what would be expected in a forest situation where growth in height normally exceeds width.

A metric frequently used in the field to judge when trees crowd is 3 to $4.5 \mathrm{~m}$ between canopy edges (McCraw, 2006). However, this underestimates the required distance between canopies in some cases and must

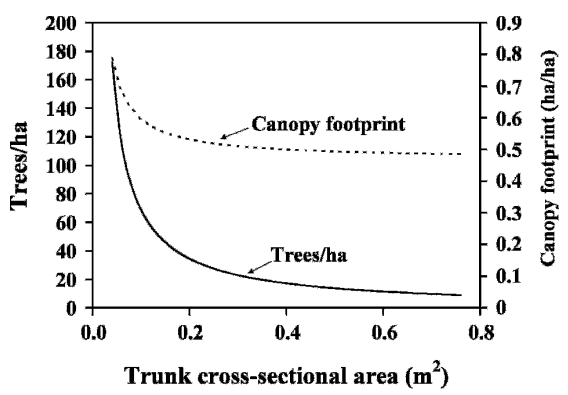

Fig. 2. Pecan tree density and canopy coverage (i.e., footprint) for various tree sizes as determined by cross-sectional trunk area per tree measured $1.4 \mathrm{~m}$ above the ground when 6.9 $\mathrm{m}^{2} \cdot \mathrm{ha}^{-1}$ of cross-sectional trunk area is maintained for each tree size, i.e., the number of trees per ha is adjusted to maintain the recommended stocking rate (Hinrichs, 1961) for each tree size.

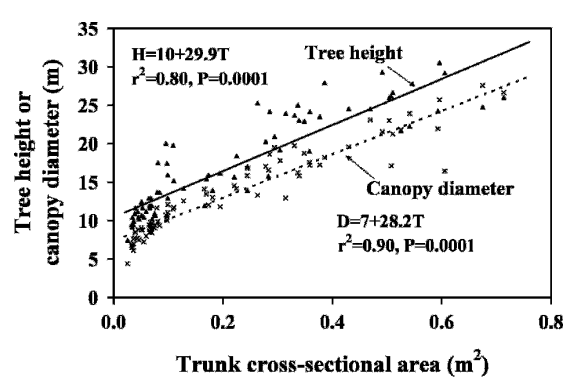

Fig. 3. The relationship between pecan tree crosssectional trunk area $(\mathrm{T})$ measured $1.4 \mathrm{~m}$ above the ground with tree height $(\mathrm{H})$ or canopy diameter (D). be increased as tree size increases to maintain recommended stocking density (Fig. 4). For instance, trees with $0.04 \mathrm{~m}^{2}(23 \mathrm{~cm}$ diameter) trunks should have $3.3 \mathrm{~m}$ between canopies at optimum tree density, increasing to $6 \mathrm{~m}$ for trees with $0.75-\mathrm{m}^{2}$ (98 $\mathrm{cm}$ diameter) trunks. Because tree height increases $\approx 3 \mathrm{~m}$ for each $0.1-\mathrm{m}^{2}$ increase in trunk area, distance between canopies must be increased to avoid excessively shading the lower canopy.

Canopy surface area and canopy volume were strongly related to cross-sectional trunk area (Fig. 5). Canopy volume increased approximately five times faster than surface area. Interior shading usually precludes substantial fruit production from the tree interior on large native pecan trees. In addition, there is little new shoot growth on the interior of large trees precluding the chance for much contribution to production. However, small trees typically have substantial interior shoot growth with adequate sunlight to support growth and production. Therefore, canopy surface area appears to be the best estimate of the tree's bearing potential when trees are large, but volume is the best estimate of bearing potential for small trees.

Canopy surface area at the recommended stocking density (Hinrichs, 1961) is initially quite high at $8.5 \mathrm{ha} \cdot \mathrm{ha}^{-1}$ land area for trees with $0.02-\mathrm{m}^{2}$ (16 $\mathrm{cm}$ diameter) trunks, but decreases rapidly to $\approx 3 \mathrm{ha} \cdot \mathrm{ha}^{-1}$ land area by the time trees have $0.2-\mathrm{m}^{2}(50 \mathrm{~cm}$ diameter $)$ trunks (Fig. 6). Canopy surface area remains at $\approx 3 \mathrm{ha} \cdot \mathrm{ha}^{-1}$ of land area through $0.75-\mathrm{m}^{2}$ $(98 \mathrm{~cm}$ diameter) trunks when trees are maintained at the recommended stocking density. Observations (Smith, unpublished

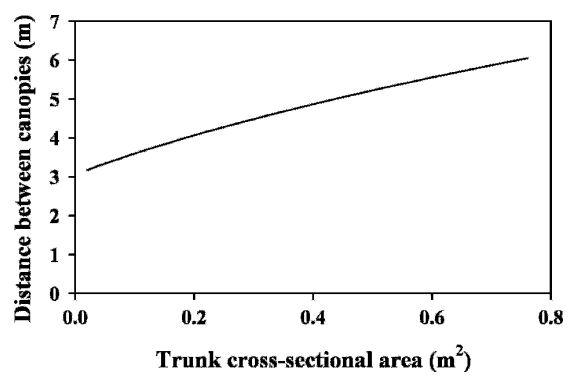

Fig. 4. The distance between pecan tree canopies for various tree sizes when maintained at the recommended density of $6.9 \mathrm{~m}^{2} \cdot \mathrm{ha}^{-1}$ of crosssectional trunk area (Hinrichs, 1961).

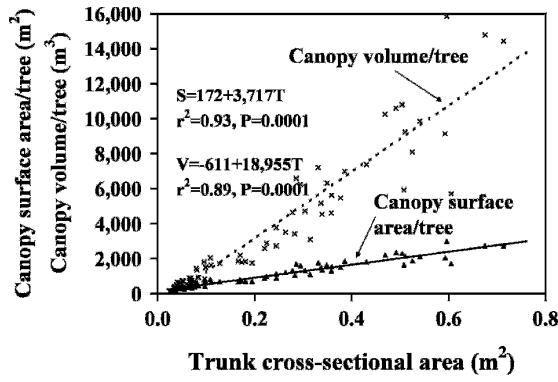

Fig. 5. The relationship between pecan tree crosssectional trunk area $(\mathrm{T})$ measured $1.4 \mathrm{~m}$ above the ground with canopy surface area (S) and canopy volume (V). 


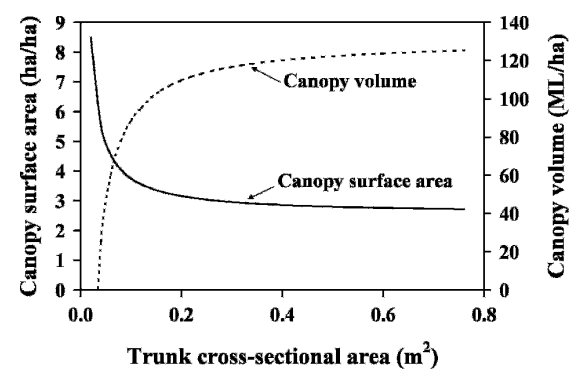

Fig. 6. Pecan canopy surface area and volume for various tree sizes as determined by crosssectional trunk area per tree measured $1.4 \mathrm{~m}$ above the ground when $6.9 \mathrm{~m}^{2} \cdot \mathrm{ha}^{-1}$ of crosssectional trunk area is maintained for each tree size, i.e., the number of trees per ha is adjusted to maintain the recommended stocking rate (Hinrichs, 1961) for each tree size.

data) and data (Hinrichs, 1961) indicate that as trees crowd, yield and nut quality decreases, probably resulting from excessive shading of the lower canopy. In fact, at extreme tree crowding, the bearing surface receiving adequate sunlight could be reduced to 1 ha $\cdot \mathrm{ha}^{-1}$, substantially reducing orchard yield potential. Canopy volume was relatively low when trees were small $\left(25 \mathrm{ML} \cdot \mathrm{ha}^{-1}\right.$ canopy volume with $0.02-\mathrm{m}^{2}$ cross-sectional trunk area), increasing rapidly to $110 \mathrm{ML} \cdot \mathrm{ha}^{-1}$ with $0.2-\mathrm{m}^{2}$ trunks. Canopy volume at the recommended density increased gradually when tree size exceeded $0.2-\mathrm{m}^{2}$ trunks.

These data support Hinrichs' (1961) conclusion that cross-sectional trunk area is a reliable guide for managing native pecan tree density. It further supports the recommendation that $50 \%$ shade at solar noon is a reliable guide for optimum tree density, but demonstrates that the required distance between canopies might be greater than stated (McCraw, 2006). It further supports observations that young trees quickly increase in production because of rapidly increasing canopy volume. However, light becomes limiting on the interior of older trees (Andersen, 1991), indicating that canopy surface area becomes the best predictor of bearing potential on large trees. Productivity of mature orchards is relatively stable when tree density is properly managed along with recommended cultural practices (McCraw, 2006; McCraw et al., 2006; Mulder and Stafne, 2007). These figures support that observation because canopy bearing surface remains relatively constant at $3 \mathrm{ha} \cdot \mathrm{ha}^{-1}$ land area at the recommended tree density (Hinrichs, 1961) once average tree size reaches or exceeds $\approx 0.2 \mathrm{~m}^{2} \cdot$ ha $^{-1}$ cross-sectional trunk area.

\section{Literature Cited}

Andersen, P.C. 1991. Photosynthetic characteristics of pecan and ten species of fruit crops with emphasis on sun tracking/non-sun tracking responses. ARS-U.S. Dept. of Agr., Agr. Res. Serv. 96:168-174.

Carroll, B., M.W. Smith, and B.D. McCraw. 2006 Establishing a pecan orchard. Okla. Coop. Ext. Serv., F-6247.
Draper, N.R. and H. Smith. 1966. Applied regression analysis. John Wiley and Sons, Inc., New York, NY.

Hall, G.D. 2000. Pecan food potential in prehistoric North America. Econ. Bot. 54:103112.

Hinrichs, H.A. 1961. The relationship of native pecan tree spacing to yield. Okla. Agr. Expt. Sta. Bul. B-574.

McCraw, B.D., G.V. Johnson, and M.W. Smith. 2006. Fertilizing pecan and fruit trees. Okla. Coop. Ext. Serv., HLA-6232.

McCraw, D. 2006. Improving native pecan groves. Okla. Coop. Ext. Serv., F-6208.

Mulder, P. and E. Stafne. 2007. Commercial pecan insect and disease control-2007. Okla. Coop. Ext. Serv., CR-6209.

Pollack, S. 2001. Fruit and tree nuts situation and outlook yearbook. USDA Market Trade Econ. Div. Econ. Res. Serv. Publ. FTS-294.

Reid, W. 2002. Current pest management systems for pecan. HortTechnology 12:633639.

Reid, W. and B. Olcott-Reid. 1985. Profits from native pecan trees. Annu. Rpt. N. Nut Growers Assn. 76:77-83.

Romberg, L.D., C.L. Smith, and H.L. Crane. 1959. Effects of irrigation and tree re-spacing (thinning) on pecan tree growth and nut production Texas Pecan Growers Assn. 38:60-75.

Smith, C.L. 1953. Proper spacing of pecan trees for greater yields, in both planted orchards and native groves. Proc. Texas Pecan Growers Assn. 32:35-37.

Smith, M.W. 2006. Pecan statistics. Oklahoma Pecan Growers' Assn. Newsletter. 47:5-8.

Smith, M.W. and B.W. Wood. 2006. Pecan tree biomass estimates. HortScience 41:1286-1291.

Sparks, D. 2005. Adaptability of pecan as a species. HortScience 40:1175-1189. 